\title{
Molecular Characterization and their Phylogenetic Relationship Based on Mitochondrial Cytochrome Oxidase I of Brinjal Shoot and Fruit Borer, Leucinodes orbonalis (Guenée) (Lepidoptera: Pyralidae)
}

\author{
S. Murali ${ }^{1 *}$, S.K. Jalali ${ }^{2}$, A.N. Shylesha ${ }^{2}$, T.M. Shivalinga Swamy ${ }^{2}$, \\ Reeta Baskar ${ }^{2}$ and Prathibha Mruthunjayaswamy ${ }^{2}$ \\ ${ }^{1}$ CSB, RSRS, Jammu - 181101, Jammu, India \\ ${ }^{2}$ NBAIR, Bengaluru - 560024, Karnataka, India \\ *Corresponding author
}

\section{A B S T R A C T}

The shoot and fruit borer, Leucinodes orbonalis has a countrywide distribution and has been categorized as the most destructive and most serious pest causing huge losses in

Keywords

Brinjal,

L. orbonalis,

Genetic distance,

Population, COI.

Article Info

Accepted:

23 June 2017

Available Online:

10 July 2017 brinjal. In the present study total of 21 populations of $L$. orbonalis collected mainly from Karnataka and also from Andhra Pradesh, New Delhi and Uttar Pradesh were molecularly characterized. The sequencing resulted in 600-636 bp product of CO I gene and amino acid composition of nucleotide, which varied from 195-206 in different populations. The certain amino acids were either present nor absent in different populations indicating their diversity. The pair-wise genetic distance of $L$. orbonalis populations ranged from 0.00 to 0.051 , suggesting that there was variation in population of $L$. orbonalis from different locations. The highest genetic distance was observed from the population of Udupi district i.e. 0.051, followed by Koppal district is 0.047 , Raichur, Chitoor, Vijayapura, Bagalkot and Guntur population having genetic distance of about 0.039 and other populations have different genetic distances which are related to each other. Therefore, it is inferred that there was no significant molecular diversity within $L$. orbonalis of different geographical locations of India with respect to COI but there is difference in the amino acid composition and genetic distance among the populations.

\section{Introduction}

The brinjal, Solanum melongena L. (Solanaceae), often referred as an eggplant or an aubergine in other regions of the world and is grown for its fleshy fruits. It is one of the widely used vegetable crops by most of the people and is popular in many countries, viz., Central, South and South East Asia, some parts of Africa and Central America (Gurubban, 1977). Brinjal is grown throughout the country, all round the year (Choudhary, 1970) and is believed to be cultivated in India for the last 4,000 years.
South East Asian countries account for almost 50 per cent of world's area under brinjal cultivation. In India, the shoot and fruit borer, Leucinodes orbonalis has a countrywide distribution and has been categorized as the most destructive and most serious pest causing huge losses in brinjal (Patil, 1990). The yield loss could be as high as 20-90 per cent in certain conditions in different states (Dhandapani et al., 2003; Kalloo, 1988; Raja et al., 1999; Sasikala et al., 1999; Jhala et al., 2003; Lal et al., 1976). The yield loss due to 
the pest is to an extent of 70-92 per cent (Eswara Reddy and Srinivas, 2004; Chakraborti and Sarkar, 2011; Jagginavar et al., 2009). It is also reported that there will be reduction in vitamin $\mathrm{C}$ content to an extent of 68 per cent in the infested fruits (Hemi, 1955).

Genetic characterization of populations of insect pests plays a pivotal role in determining management strategies of the insect pest (Guirao et al., 1997). Use of isozymes as biochemical marker to study the insect populations began in the late 1950s and continues to be widely applied (Black et al., 1992). Within the last few years, techniques using the polymerase chain reaction (PCR) to amplify specific genomic regions have become widespread (Saiki et al., 1988; Mullis and Faloona, 1987). Williams et al., (1990) developed the technique that uses a single decamer primer to amplify arbitrary regions of a genome. They demonstrated that RAPDPCR process reveals polymorphisms in the genomes of a wide variety of insect species. Molecular characterization of insects has been frequently conducted on the basis of existence of polymorphic DNA fragments amplified by PCR. Williams et al., (1994) have reported geographical distribution of Argentine stem weevils, Listronotus bonariensis (Kuschel), by RAPD-PCR using genomic DNAs. Haymer and McInnis (1994) have also pointed out a distinctive variation in PCRamplified DNA patterns between laboratory cultured and wild populations of Mediterranean fruit flies, Ceratitis capitata (Weidemann). Molecular marker technology is a powerful tool in analyzing the phylogeny, evolution and population dynamics in insects (Symondson and Liddell, 1996; Smith and Wayne, 1996).

The number of polymorphic markers was higher indicating the diversity among the Leucinodes populations (Lynch and Milligan, 1994; Williams et al., 1990). Similar results were recorded in other pests like screwworm flies (Barum et al., 1995) and Mediterranean fruit fly (Haymer et al., 1997; Infante Malachias et al., 1999; Boulding, 1998). Genetic similarities among geographical populations from the data were within the similarity coefficients ranging from 0.41 to 0.77 . Host mediated variation has also been reported (John et al., 2002). Karthikeyan et al., (2005) studied six different populations of L. orbonalis were collected and subjected to analysis of genetic variability in terms of carboxylesterase isozyme pattern and DNA polymorphism using RAPDPCR. Pattern of carboxylesterase revealed a similar isozyme cluster in the populations namely, Sivaganga (population-3), Dindigal (population-4), Virudhunagar (population-5) and Coimbatore (population-6). Similarly, the populations of L. orbonalis recorded 3 distinct randomly amplified polymorphic DNA markers in all populations grouped above. This pattern of genetic variability in the populations was also supported by the analysis of the similarity indices and UPGMA dendrogram. Mitochondrial genes are commonly used for evolutionary studies as they have a number of characteristics such as (i) maternal inheritance with little or no recombination, (ii) general conserved gene and composition, (iii) small size of gene and (iv) lack of introns (Gissi et $a l ., 2008)$. In the present study, an attempt was made to use cytochrome oxidase subunit 1 (COI) gene for understanding the genetic variations among Leucinodes species bred on brinjal.

\section{Materials and Methods}

\section{Collection of shoot and fruit borer}

Twenty one different populations of shoot and fruit borer larvae were collected from damaged brinjal shoots and fruits from different places of Karnataka and other states like Andhra Pradesh, New Delhi and Uttar Pradesh (Table 1). 


\section{Molecular characterization}

DNA was extracted from the larvae using Qiagen D Neasy ${ }^{\circledR}$ kit/ CTAB method, following the protocols of manufacturers. The DNA obtained by either of the methods mentioned above was checked for its quality by agarose gel electrophoresis.

The gel was prepared by dissolving 0.8 per cent agarose in 1x TBE buffer and boiled. About $2 \mu \mathrm{l}$ of ethidium bromide (EtBr) was added to $50 \mathrm{ml}$ of the agarose and poured in the electrophoresis template placed with comb and allowed to solidify for around $40 \mathrm{~min}$.

Thereafter, it was placed in the gel electrophoresis unit with running buffer. The DNA samples were loaded into the wells and electrophoresised at $80 \mathrm{~mA}$ at 150 volts for 30 min. It was observed under UV illuminator and documented in DNA bioimaging systems using gel capture software.

The DNA with high quality was taken for the amplification of the particular sequences using $\mathrm{CO} 1$ primers. The CO1 amplification was carried out for the DNA samples with the master mix and temperature conditions as follows: Template DNA $(2 \mu 1)$, Taq buffer (3 $\mu \mathrm{l})$, DNTPs $(1 \mu \mathrm{l})$, Forward primer $(2 \mu \mathrm{l})$, Reverse primer $(2 \mu \mathrm{l})$, Taq polymerase $(1 \mu \mathrm{l})$, Water $(19 \mu \mathrm{l})$ and total reaction volume $(30$ $\mu \mathrm{l})$. The temperature profile having initial denaturation $\left(94^{\circ} \mathrm{C}\right.$ for $\left.5 \mathrm{~min}\right)$, Denaturation $\left(94{ }^{\circ} \mathrm{C}\right.$ for $\left.1 \mathrm{~min}\right)$, Annealing $\left(45^{\circ} \mathrm{C}\right.$ for 30 min), Extension $\left(72{ }^{\circ} \mathrm{C}\right.$ for $\left.1 \mathrm{~min}\right)$, Repeat step 2 to step 4 for 35 cycles, Final extension $\left(72{ }^{\circ} \mathrm{C}\right.$ for $10 \mathrm{~min}$ ) and hold at $40^{\circ} \mathrm{C}$ for $5 \mathrm{~min}$.

The primer sequence of $\mathrm{CO} 1$ used was Forward primer: 5, GGTCAACAAATCATAAAGATATTGG 3' and Reverse primer: 5' TAAACTTCAGGCTGACCAAAAAATCA 3'. The master mix was mixed with DNA template and Taq polymerase was added at last separately. It should be noted that the whole reaction mix should be prepared by keeping it on ice. As soon as the reaction mix is prepared and dispensed, the PCR tubes are kept in the wells of the thermal cycler and the temperature conditions are set and run.

Agarose gel of 1.5 per cent was used to observe the amplified products which was loaded and run at $80 \mathrm{~mA}$ at 150 volts for 30 min. The amplified sequences were sent for sequencing to $\mathrm{M} / \mathrm{s}$ Chromous Biotech Pvt. Ltd., Bengaluru, for sequencing and the nucleotides were retrieved from the trace files provided. The sequences were analysed in BLAST (Basic Local Alignment Search Tool) to check the homology of the partial sequences and annotated. The sequences were then submitted to GenBank and the accession numbers were received.

\section{Results and Discussion}

\section{DNA isolation from Leucinodes species breeding on brinjal crop}

The DNA was isolated from matured larvae of Leucinodes species collected on brinjal crop from diverse regions of Karnataka and other states. The sequences obtained from the 21 populations were deposited in GenBank and through blast similarity test; all specimens were confirmed to be $L$. Orbonalis (Table 1).

\section{Mitochondrial cytochrome oxidase (mtCOI) gene analyses of Leucinodes species breeding on brinjal}

PCR analysis of mtCOI region of 21 individuals of Leucinodes species breeding on brinjal collected from 21 locations were amplified (Fig. 1). The sequencing of PCR products by using custom services revealed various sequences of test isolates which ranged from 600-636 bp. 
Computation of amino acids composition of Leucinodes specimen on brinjal nucleotide sequences

The data concerning amino acids composition of $L$. orbonalis specimens collected on brinjal, from different locations is given in table 2. The total number of amino acids among 21 Leucinodes specimens varied from 195 to 206. The highest value recorded for number of amino acids was 206, collected on brinjal from Chitradurga, while in other populations it ranged from 195 to 203 and in the out group population of $L$. orbonalis from South Africa, 200 aminoacids were recorded (Table 2).

The 21 L. orbonalis specimens collected from different places, showed variation in their amino acid composition. Populations collected from Koppal showed presence of cysteine amino acid, but others showed absence of that amino acid. The population collected from Udupi district showed absence of glutamine amino acid but others showed presence of that amino acid in all the populations. The population collected from Mandya showed the presence of tryptophan and all others showed absence of that amino acid. None of the populations showed the presence of methionine amino acid. The average of amino acid composition was highest in isoleucine (17.94), followed by leucine (14.76) (Table 2).

Pair-wise genetic distances between Leucinodes species breeding on brinjal

The pair-wise genetic distance of $L$. orbonalis populations ranged from 0.00 to 0.051 (Table 3 ), suggesting variation in population of $L$. orbonalis from different locations. The highest genetic distance was observed from the population of Udupi district (0.051) followed by Koppal district (0.047), Raichur, Chitoor, Vijayapura, Bagalkot and Guntur population having genetic distance of 0.039 and other populations had different genetic distances which are related to each other. The lowest genetic distance between populations was evident in populations of Kolar, Bagalkot, Vijayapura, Chittoor, Raichur, Kalaburgi, and out group from South Africa (0.00) (Table 3).

Phylogenetic analysis of aligned mtCOI gene sequences for genetic relatedness amongst Leucinodes species breeding on brinjal

Based on the bootstrap consensus Neighbouring joining tree, genetic differences were observed between populations of different locations having geographical distribution with two major clades (Fig. 2; Table 3). The first major clade can be divided into two sub clades. The first subclade can be again divided into two clusters.

The population from Guntur and Bagalkot were clustered together and their genetic distances varied from 0.00-0.03 and showed genetic variation and were separated from other populations. The population from Vijayapura separated from above cluster was having a genetic distance of about 0.03 (Fig. 2). The population from Chittoor and Raichur were clustered together and showed genetic distance of 0.00-0.039 from percent pairwise genetic analysis.

The population from Belagavi separated from the above cluster was having a genetic distance of about 0.018. The Bengaluru and Yadgiri population was clustered together having a genetic distance which varied from 0.004-0.029 and showed lowest level of genetic distance. The Shivamogga and Doddaballapur population was clustered together and having genetic distance which varied from 0.013-0.037 (Fig. 2; Table 3). 
Table.1 Details of GenBank accession numbers of COI region different population of Leucinodes orbonalis

\begin{tabular}{|c|c|c|c|c|c|c|}
\hline Sl. No. & Strain Name & Code Name & Population name & Total base pairs & Bankit id & Accession number \\
\hline 1 & LO-HASSAN-C1 & HSN & HASSAN & 624 & 1790928 & KP641172 \\
\hline 2 & LO-VARANASI-C1 & VRN & VARANASI & 618 & 1790936 & KP641173 \\
\hline 3 & LO-BELAGAVI-C1 & BGM & BELAGAVI & 624 & 1790940 & KP641174 \\
\hline 4 & LO-DHARWAD-C1 & DWD & DHARWAD & 623 & 1791489 & KP659261 \\
\hline 5 & LO-SHIVAMOGGA-C1 & SMG & SHIVAMOGGA & 624 & 1791490 & KP659262 \\
\hline 6 & LO-DODDABALLAPUR-C1 & DBP & DODDABALLAPUR & 624 & 1791491 & KP659263 \\
\hline 7 & LO-ANANTAPUR (AP)-C1 & ANT & ANANTAPUR (AP) & 624 & 1792096 & KP662094 \\
\hline 8 & LO-MANDYA-C1 & MDA & MANDYA & 621 & 1792100 & KP662095 \\
\hline 9 & LO-GUNTUR(AP)-C1 & GTR & GUNTUR(AP) & 624 & 1792102 & KP662096 \\
\hline 10 & LO- NEW DELHI-C1 & NDL & NEW DELHI & 624 & 1792626 & KP676169 \\
\hline 11 & LO-KOLAR-C1 & KLR & KOLAR & 624 & 1792633 & KP676170 \\
\hline 12 & LO-CHITRADURGA-C1 & $\mathrm{CDG}$ & CHITRADURGA & 636 & 1792637 & KP676171 \\
\hline 13 & LO-BAGALKOT-C1 & $\mathrm{BKT}$ & BAGALKOT & 606 & 1792640 & KP676172 \\
\hline 14 & LO-VIJAYAPURA-C1 & BJR & VIJAYAPURA & 600 & 1792644 & KP676173 \\
\hline 15 & LO-BENGALURU-C1 & $\mathrm{BNG}$ & BENGALURU & 606 & 1793380 & KP687242 \\
\hline 16 & LO-CHITTOOR (AP)-C1 & CTR & CHITTOOR (AP) & 600 & 1793388 & KP687243 \\
\hline 17 & LO-RAICHUR-C1 & RCR & RAICHUR & 600 & 1793398 & KP687244 \\
\hline 18 & LO-KALABURGI-C1 & GBG & KALABURGI & 600 & 1793402 & KP687245 \\
\hline 19 & LO-KOPPAL -C1 & KPL & KOPPAL & 615 & 1793903 & KP693449 \\
\hline 20 & LO-UDUPI-C1 & UDP & UDUPI & 615 & 1793906 & KP693450 \\
\hline 21 & LO-YADGIRI-C1 & YDG & YADGIRI & 603 & 1793910 & KP693451 \\
\hline 22 & LN- OUT GROUP-C1 & - & SOUTH AFRICA & 618 & - & LN624707.1 \\
\hline
\end{tabular}


Table.2 Computation of amino acids composition of different populations of Leucinodes recorded from brinjal

\begin{tabular}{|c|c|c|c|c|c|c|c|c|c|c|c|c|c|c|c|c|c|c|c|c|c|}
\hline Populations & Ala & Cys & Asp & Glu & Phe & Gly & His & Ile & Lys & Leu & Met & Asn & Pro & Gln & Arg & Ser & Thr & Val & Trp & Tyr & Total \\
\hline HSN & 7.39 & 0.00 & 3.45 & 0.49 & 6.40 & 10.34 & 1.48 & 17.73 & 0.99 & 14.78 & 0.00 & 6.40 & 6.40 & 0.49 & 3.45 & 7.88 & 6.40 & 4.43 & 0.00 & 1.48 & 203.00 \\
\hline VRN & 7.46 & 0.00 & 2.99 & 0 & 97 & 0.45 & 9 & 7.41 & 1.00 & .93 & 00 & 6.47 & 5.97 & 50 & .99 & 7.96 & 47 & 1.48 & 00 & 49 & 01.00 \\
\hline BGM & 7.39 & 0.00 & 3.45 & 0.99 & 6.40 & 10.34 & 1.48 & 17.24 & 0.49 & 14.78 & 0.00 & 6.40 & 6.40 & 0.49 & 3.45 & 8.37 & 6.40 & 4.43 & .00 & 1.48 & 203.00 \\
\hline DWD & 7.39 & 0.00 & 3.45 & 0.49 & 6.40 & 10.34 & 1.48 & 17.73 & 0.99 & 14.78 & 0.00 & 5.91 & 6.40 & 0.49 & 3.45 & 8.37 & 6.40 & 4.43 & 0.00 & 1.48 & 203.00 \\
\hline SMG & 7. & 0.00 & 3.45 & 0 & 6.40 & 10.34 & 1.48 & 17.24 & 0.99 & 14.78 & 0.00 & 6.40 & 6.40 & 0.49 & 3.45 & 8.37 & 6.40 & 4.43 & 0.00 & 1.48 & 03.00 \\
\hline DBP & 7.35 & 0.00 & 2.94 & 0.49 & 6.37 & 10.29 & 1.96 & 17.16 & 0.98 & 14.22 & 0.00 & 6.86 & 5.88 & 0.49 & 3.92 & 8.33 & 7.35 & 4.41 & 0.00 & 0.98 & 204.00 \\
\hline ANT & 7.39 & 0.00 & 3.45 & 0 & 6.40 & 10.34 & 1.48 & 17.73 & 0.99 & 14.78 & 00 & 6.40 & 6.40 & 49 & 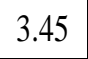 & 7.88 & .40 & 4.43 & 00 & .48 & 03.00 \\
\hline MDA & 7 & 0.00 & 3. & 0.49 & 6.40 & 10.34 & 48 & 17.24 & 0.99 & 4.78 & 0.00 & 6.40 & 6.40 & 0.49 & 3.45 & 7.88 & 6.40 & 4.43 & 49 & 1.48 & 203.00 \\
\hline GTR & 7.39 & 0.00 & 3.45 & 0.99 & 6.40 & 9.36 & 1.48 & 17.73 & 0.49 & 14.78 & 0.00 & 6.40 & 6.40 & 0.49 & 4.43 & 7.88 & 6.40 & 4.43 & 0.00 & 1.48 & 203.00 \\
\hline NDL & 730 & 000 & 3.45 & 0 & 640 & 10.34 & 148 & 1773 & 0.90 & 14.78 & 000 & 6.40 & 6.40 & 049 & 345 & 7.88 & 640 & 4.43 & 00 & 1.48 & 203.00 \\
\hline KLR & 7.39 & 0.00 & 3.45 & 0.49 & 6.40 & 9.85 & 1.48 & 17.73 & 0.99 & 14.78 & 0.00 & 6.40 & 6.40 & \begin{tabular}{|l|l|} 
\\
\end{tabular} & 3.94 & 7.88 & 6.40 & 4.43 & 0.00 & 1.48 & 203.00 \\
\hline CDG & 7.77 & 0.00 & 3.40 & 0.97 & 6.31 & 10.68 & 1.46 & 17.96 & 0.49 & 14.56 & 0.00 & 6.31 & 6.31 & \begin{tabular}{|l}
0.49 \\
\end{tabular} & 3.40 & 7.77 & 6.31 & 4.37 & 0.00 & 1.46 & 206.00 \\
\hline BKT & 7.61 & 0.00 & 3.05 & 10 & 660 & 10.15 & 152 & 1878 & 051 & 14.72 & 0.00 & 660 & 6.09 & 0.51 & $0.0 J$ & 761 & ho & 4.57 & 0.00 & 02 & 97.00 \\
\hline BJR & 7.69 & 0.00 & 2.56 & 1.05 & 0.01 & 10.26 & 1.54 & 18.97 & 0.31 & 14.87 & 0.00 & 6.67 & 5.64 & 0.51 & 3.59 & 7.69 & 6.15 & 4.62 & 0.00 & 1.03 & 195.00 \\
\hline BNG & 7.61 & 0.00 & 3.05 & 1.02 & 6.60 & 10.15 & 1.52 & 18.78 & 0.51 & 14.72 & 0.00 & 6.60 & 6.09 & 0.51 & 3.55 & 7.61 & 6.09 & 4.57 & 0.00 & 1.02 & 197.00 \\
\hline CTR & T & 0.00 & 2.56 & 1.03 & 6.67 & 10.26 & 1.54 & 18.97 & 0.51 & 14.87 & 0.00 & 6.67 & 5.64 & 0.51 & 3.59 & 7.69 & 6.15 & 4.62 & 0.00 & 1.03 & 95.00 \\
\hline RCR & 7.69 & 0.00 & 2.56 & 1.03 & 6.67 & 10.26 & 1.54 & 18.97 & 0.51 & 14.87 & 0.00 & 6.67 & 5.64 & 0.51 & 3.59 & 7.69 & 6.15 & 4.62 & 0.00 & 1.03 & 195.00 \\
\hline GBG & 7.69 & 0.00 & 2.56 & 1.03 & 6.67 & 10.26 & 1.54 & 18.97 & 0.51 & 14.87 & 0.00 & 6.67 & 5.64 & 0.51 & 3.59 & 7.69 & 6.15 & 4.62 & 0.00 & 1.03 & 195.00 \\
\hline KPL & 8.96 & 0.50 & 2.4 & 1.00 & 0. & 10.45 & 1.49 & 17.41 & 0.5 & 14.93 & 0. & 6.47 & 5.97 & 0.00 & 5.90 & 7.96 & 5.47 & 4.98 & 0.00 & 1.49 & 201.00 \\
\hline UDP & 7.96 & 0.00 & 2.49 & 1.49 & 5.97 & 10.45 & 1.49 & 17.41 & 0.50 & 14.93 & 0.00 & 5.97 & 5.97 & 0.00 & 4.98 & 7.96 & 6.47 & 4.98 & 0.00 & 1.00 & 201.00 \\
\hline YDG & 7.65 & 0.00 & 3.57 & 1.02 & 6.63 & 10.20 & 1.53 & 17.86 & 0.51 & 14.80 & 0.00 & 6.63 & 6.63 & 0.51 & 3.57 & 7.14 & 6.12 & 4.08 & 0.00 & 1.53 & 196.00 \\
\hline $\begin{array}{l}\text { LN624707.1 } \\
\text { (Out group) }\end{array}$ & 8.00 & 0.00 & 3.50 & 1.00 & 6.00 & 11.50 & 1.50 & 18.00 & 0.50 & 14.50 & 0.00 & 6.50 & 6.00 & 0.50 & 3.50 & 7.50 & 6.00 & 4.50 & 0.00 & 1.00 & 200.00 \\
\hline Avg. & 7.62 & 0.02 & 3.13 & 82 & 6.37 & .32 & 54 & .94 & 0.70 & .76 & 00 & 6.46 & 6.19 & 0.48 & 3.65 & 7.87 & 6.30 & 4.51 & 0.02 & 1.29 & 00.45 \\
\hline
\end{tabular}


Table.3 Pair wise genetic distance based on mt.COI gene sequences of Leucinodes spp. recorded from brinjal

\begin{tabular}{|c|c|c|c|c|c|c|c|c|c|c|c|c|c|c|c|c|c|c|c|c|c|c|}
\hline Populations & 1 & 2 & 3 & 4 & 5 & 6 & 7 & 8 & 9 & 10 & 11 & 12 & 13 & 14 & 15 & 16 & 17 & 18 & 19 & 20 & 21 & 22 \\
\hline HSN & & 0.004 & 0.006 & 0.005 & 0.005 & 0.007 & 0.003 & 0.004 & 0.006 & 0.004 & 0.003 & 0.004 & 0.006 & 0.006 & 0.004 & 0.006 & 0.006 & 0.004 & 0.007 & 0.008 & 0.004 & 0.004 \\
\hline VRN & 0.011 & & 0.006 & 0.005 & 0.005 & 0.008 & 0.003 & 0.004 & 0.006 & 0.002 & 0.003 & 0.003 & 0.006 & 0.006 & 0.004 & 0.006 & 0.006 & 0.003 & 0.007 & 0.007 & 0.004 & 0.003 \\
\hline BGM & 0.018 & 0.018 & & 0.007 & 0.005 & 0.009 & 0.005 & 0.006 & 0.002 & 0.005 & 0.005 & 0.005 & 0.002 & 0.002 & 0.005 & 0.002 & 0.002 & 0.005 & 0.008 & 0.008 & 0.004 & 0.005 \\
\hline DWD & 0.015 & 0.015 & 0.026 & & 0.006 & 0.008 & 0.004 & 0.004 & 0.007 & 0.004 & 0.004 & 0.005 & 0.007 & 0.007 & 0.005 & 0.007 & 0.007 & 0.005 & 0.008 & 0.008 & 0.005 & 0.005 \\
\hline SMG & 0.016 & 0.013 & 0.016 & 0.020 & & 0.008 & 0.004 & 0.005 & 0.006 & 0.004 & 0.004 & 0.004 & 0.006 & 0.006 & 0.005 & 0.006 & 0.006 & 0.004 & 0.008 & 0.008 & 0.005 & 0.004 \\
\hline DBP & 0.029 & 0.030 & 0.037 & 0.033 & 0.031 & & 0.006 & 0.007 & 0.009 & 0.007 & 0.006 & 0.007 & 0.009 & 0.009 & 0.007 & 0.009 & 0.009 & 0.007 & 0.010 & 0.011 & 0.007 & 0.007 \\
\hline ANT & 0.005 & 0.005 & 0.016 & 0.009 & 0.011 & 0.024 & & 0.002 & 0.005 & 0.002 & 0.000 & 0.002 & 0.005 & 0.005 & 0.002 & 0.005 & 0.005 & 0.002 & 0.007 & 0.007 & 0.003 & 0.002 \\
\hline MDA & 0.009 & 0.009 & 0.020 & 0.013 & 0.015 & 0.028 & 0.004 & & 0.006 & 0.003 & 0.002 & 0.004 & 0.006 & 0.006 & 0.003 & 0.006 & 0.006 & 0.004 & 0.007 & 0.007 & 0.004 & 0.004 \\
\hline GTR & 0.016 & 0.016 & 0.002 & 0.024 & 0.018 & 0.039 & 0.014 & 0.018 & & 0.005 & 0.005 & 0.004 & 0.000 & 0.000 & 0.004 & 0.000 & 0.000 & 0.004 & 0.008 & 0.007 & 0.004 & 0.004 \\
\hline NDL & 0.007 & 0.004 & 0.015 & 0.011 & 0.009 & 0.026 & 0.002 & 0.005 & 0.013 & & 0.002 & 0.002 & 0.005 & 0.005 & 0.003 & 0.005 & 0.005 & 0.002 & 0.006 & 0.007 & 0.003 & 0.002 \\
\hline KLR & 0.005 & 0.005 & 0.016 & 0.009 & 0.011 & 0.024 & 0.000 & 0.004 & 0.014 & 0.002 & & 0.002 & 0.005 & 0.005 & 0.002 & 0.005 & 0.005 & 0.002 & 0.007 & 0.007 & 0.003 & 0.002 \\
\hline $\mathrm{CDG}$ & 0.009 & 0.005 & 0.013 & 0.013 & 0.011 & 0.028 & 0.004 & 0.007 & 0.011 & 0.002 & 0.004 & & 0.004 & 0.004 & 0.003 & 0.004 & 0.004 & 0.000 & 0.006 & 0.006 & 0.003 & 0.000 \\
\hline BKT & 0.016 & 0.016 & 0.002 & 0.024 & 0.018 & 0.039 & 0.014 & 0.018 & 0.000 & 0.013 & 0.014 & 0.011 & & 0.000 & 0.004 & 0.000 & 0.000 & 0.004 & 0.008 & 0.007 & 0.004 & 0.004 \\
\hline BJR & 0.016 & 0.016 & 0.002 & 0.024 & 0.018 & 0.039 & 0.014 & 0.018 & 0.000 & 0.013 & 0.014 & 0.011 & 0.000 & & 0.004 & 0.000 & 0.000 & 0.004 & 0.008 & 0.007 & 0.004 & 0.004 \\
\hline BNG & 0.009 & 0.009 & 0.013 & 0.013 & 0.015 & 0.028 & 0.004 & 0.007 & 0.011 & 0.005 & 0.004 & 0.004 & 0.011 & 0.011 & & 0.004 & 0.004 & 0.003 & 0.007 & 0.007 & 0.003 & 0.003 \\
\hline CTR & 0.016 & 0.016 & 0.002 & 0.024 & 0.018 & 0.039 & 0.014 & 0.018 & 0.000 & 0.013 & 0.014 & 0.011 & 0.000 & 0.000 & 0.011 & & 0.000 & 0.004 & 0.008 & 0.007 & 0.004 & 0.004 \\
\hline RCR & 0.016 & 0.016 & 0.002 & 0.024 & 0.018 & 0.039 & 0.014 & 0.018 & 0.000 & 0.013 & 0.014 & 0.011 & 0.000 & 0.000 & 0.011 & 0.000 & & 0.004 & 0.008 & 0.007 & 0.004 & 0.004 \\
\hline GBG & 0.009 & 0.005 & 0.013 & 0.013 & 0.011 & 0.028 & 0.004 & 0.007 & 0.011 & 0.002 & 0.004 & 0.000 & 0.011 & 0.011 & 0.004 & 0.011 & 0.011 & & 0.006 & 0.006 & 0.003 & 0.000 \\
\hline KPL & 0.028 & 0.024 & 0.032 & 0.032 & 0.030 & 0.047 & 0.022 & 0.026 & 0.030 & 0.020 & 0.022 & 0.018 & 0.030 & 0.030 & 0.022 & 0.030 & 0.030 & 0.018 & & 0.008 & 0.007 & 0.006 \\
\hline UDP & 0.032 & 0.028 & 0.032 & 0.035 & 0.032 & 0.051 & 0.026 & 0.030 & 0.030 & 0.024 & 0.026 & 0.022 & 0.030 & 0.030 & 0.024 & 0.030 & 0.030 & 0.022 & 0.030 & & 0.007 & 0.006 \\
\hline YDG & 0.011 & 0.011 & 0.011 & 0.015 & 0.013 & 0.029 & 0.005 & 0.009 & 0.009 & 0.007 & 0.005 & 0.005 & 0.009 & 0.009 & 0.005 & 0.009 & 0.009 & 0.005 & 0.024 & 0.026 & & 0.003 \\
\hline $\begin{array}{c}\text { LN624707.1 } \\
\text { Out group }\end{array}$ & 0.009 & 0.005 & 0.013 & 0.013 & 0.011 & 0.028 & 0.004 & 0.007 & 0.011 & 0.002 & 0.004 & 0.000 & 0.011 & 0.011 & 0.004 & 0.011 & 0.011 & 0.000 & 0.018 & 0.022 & 0.005 & \\
\hline
\end{tabular}


Fig.1 PCR amplification of mtCOI region with L. orbonalis population collected from Different locations with universal Folmer primers
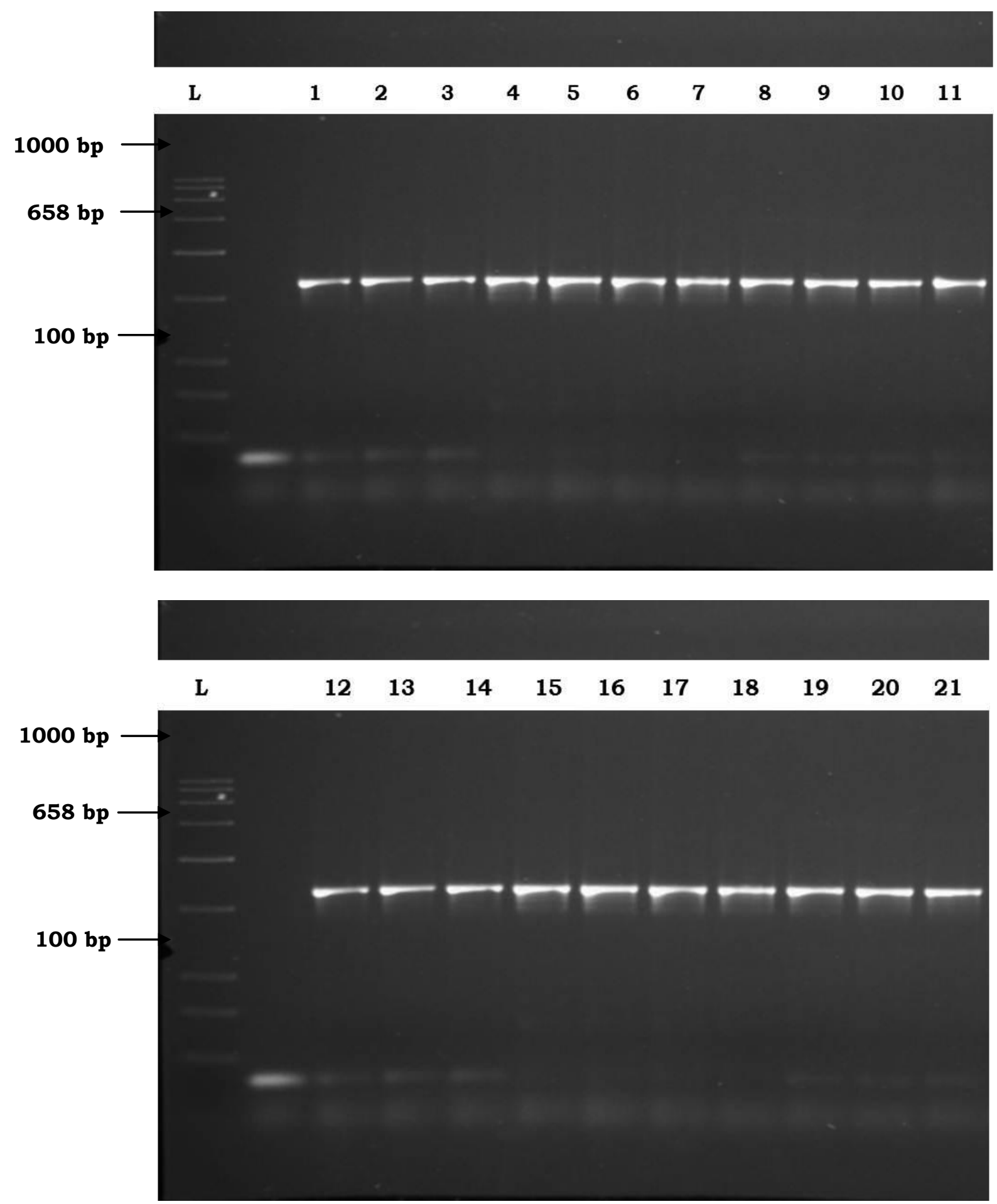

Note: 1. Hassan 2. Varanasi 3. Dharwad 4. Shimoga 5. Belgaum 6. Koppal 7. Bangalore rural 8. Ananthapur 9. Mandya 10. Guntur 11. Udupi 12. New Delhi 13. Kolar 14. Chitradurga 15. Bagalkot 16. Bijapur (Vjayapur) 17. Raichur 18. Gulberga (Kalaburgi) 19. Yadagiri 20. Bangalore urban 21. Chittoor 
Fig.2 Original tree based on Tamura 3-parameter model for CO1 DNA sequences for different L. orbonalis populations based on Maximum likelihood bootstrap method for 2000 replications (Bootstrap consensus tree). CO1 sequence from L. orbonalis (accession \#LN624707.1) was

Used as out group sequence

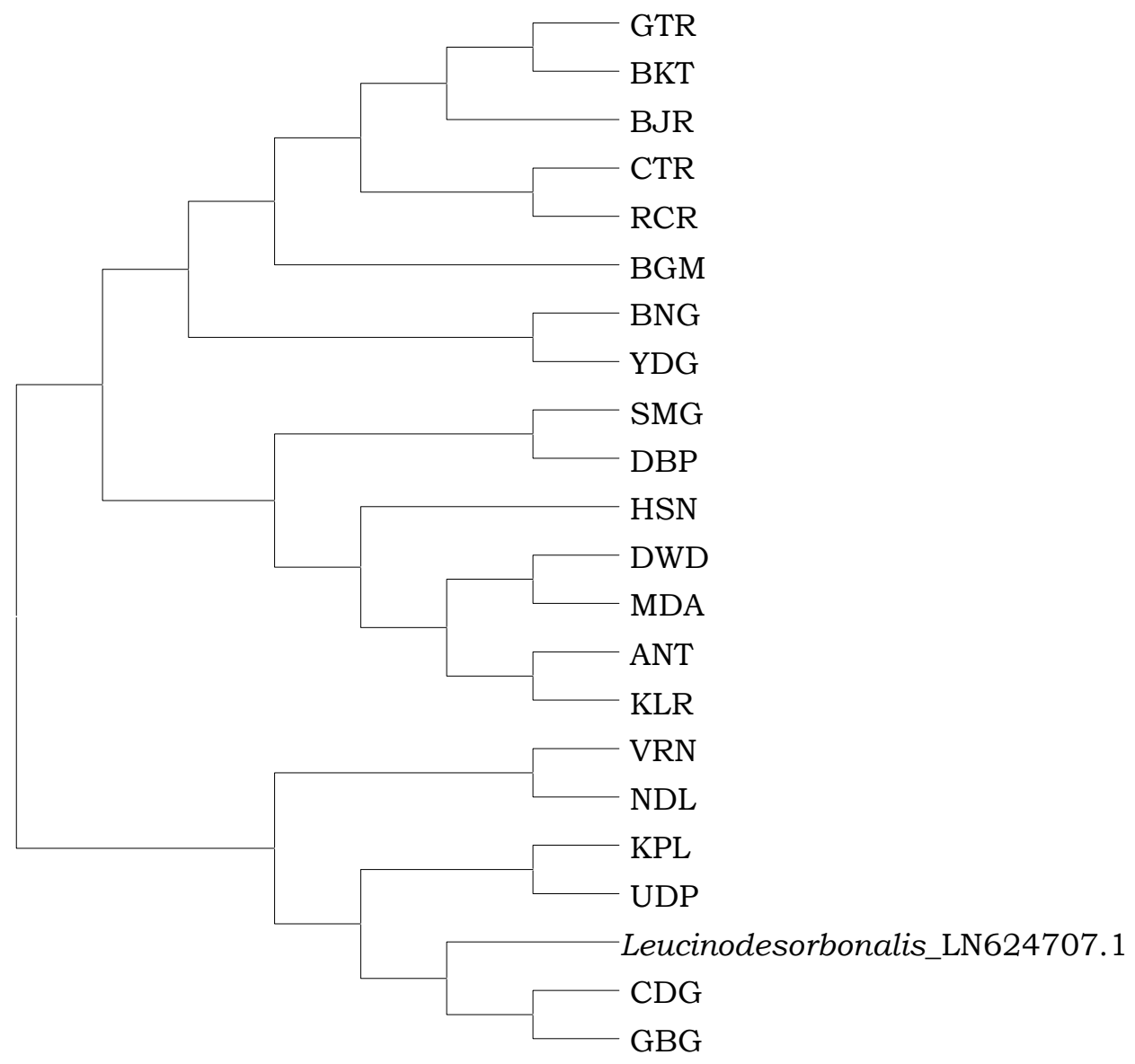

The population from second clade is again subdivided into two subclades, the population from Varanasi and New Delhi was clustered together which showed the population having lowest variation and the genetic distance varied from 0.002-0.010. The population from Koppal and Udupi was clustered together which showed the population having lowest variation and the genetic distance varied from 0.018-0.051. The other cluster was again divided into three subclusters, the population from Chitradurga and Kalaburgi were clustered together and were having the genetic distance that varied from $0.000-0.028$ and showed genetic differences.
The population from South Africa as out group showed relatedness towards the populations from Chitradurga and Kalaburgi and showed similarity of species having the lowest genetic distance that varied from 0.000-0.028 (Fig. 2; Table 3).

Genetic characterization of populations of insect pests plays a pivotal role in determining management strategies of the insect pest (Guirao et al., 1997). Use of isozymes as biochemical marker to study the insect populations began in the late 1950s and continues to be widely applied (Black et al., 1992). Within the last few years, techniques 
using the polymerase chain reaction (PCR) to amplify specific genomic regions have become widespread (Saiki et al., 1988; Mullis and Faloona, 1987). Williams et al., (1990) developed the technique that uses a single decamer primer to amplify arbitrary regions of a genome. They demonstrated that RAPDPCR process reveals polymorphisms in the genomes of a wide variety of insect species.

It was important to distinguish Leucinodes species breeding on brinjal crop using mitochondrial DNA markers as a standard identification protocol. Molecular diversity studies in various insects of importance in agriculture helped in identifying new species (Ball and Armstrong, 2006), biotypes (Perring, 2001) cryptic species (Hebert et al., 2004) pheromone and voltinism races (Marcon et al., 1999) and haplotypes (Toda and Murai, 2007), which are difficult to identify through morphological characters. The extent of genetic variation between geographical populations depends on several factors, including gene flow between populations, host range, environment and time since separation (Baker and Stebbins, 1965; Hartl, 1980). In view of this, understanding the genetic differences among the populations of L. orbonalis using COI nucleotide sequence will provide better understating of genetic diversity. Studies of genetic variability could help to decide whether the entire $L$. orbonalis is in fact a single interbreeding population in which strong gene flow can occur. Assessing the genetic variability could help to design the management strategies of the insect pests (Marimuthu et al., 2009).

Mitochondrial genes are commonly used for evolutionary studies as they have a number of characteristics such as (i) maternal inheritance with little or no recombination, (ii) general conserved gene and composition, (iii) small size of gene and (iv) lack of introns (Gissi et al., 2008). In the present study, an attempt was made to use cytochrome oxidase subunit 1 (COI) gene for understanding the genetic variations among Leucinodes species bred on brinjal. During the study, COI genes for 21 populations of brinjal were obtained from 21 different locations using cytochrome oxidase subunit 1 (COI) gene showed that all population has identity as L. orbonalis.

In the present investigation the results from Cytochorome C Oxidase I (COI) gene showed that nucleotide analysis of genetic diversity and phylogenetic analysis of the COI indicate that, the $L$. orbonalis from different geographical regions are homogenous and the populations showed having overall mean distance $(0.015 \pm 0.003)$, which is in agreement with reports by Shashank et al., (2015). Topologies of neighbour-joining (NJ) trees indicate all the populations belong to single major clade. Therefore, it is inferred that there was no significant molecular diversity within L. orbonalis of different geographical locations of India with respect to COI.

The present analysis showed that average nucleotide composition from the populations was $31.95 \%$ (A), $39.89 \%$ (T/U), $14.36 \%$ (C), and $13.80 \%(\mathrm{G})$. Similar study has reported by Shashank et al., (2015), the average nucleotide composition across all $L$. orbonalis was $\mathrm{A}=31.8 \%, \mathrm{~T}=40.0 \%, \mathrm{C}=$ $13.3 \%$ and $\mathrm{G}=14.9 \%$. The pair-wise genetic distance of $L$. orbonalis populations ranged from 0.00 to 0.051 , suggesting that there is not much variation in population of $L$. orbonalis from different locations, which corroborates with findings of (Shashank et al., 2015). Marimuthu et al., (2009) investigated that, random-amplified polymorphic DNA markers were used to assess the genetic diversity of $L$. orbonalis population collected from different field locations of Tamil Nadu and reported that out of 17 random-amplified polymorphic DNA primers screened, only 11 
primers generated polymorphic bands (up to 14 bands). According to their level of similarities, only two major clusters with no variation among population were deduced.

The present finding suggests that there was no wider difference in the case of existing population of $L$. orbonalis, which is similar to findings of Geetha Rajalakshmi et al., (2006), who worked out the mean similarity for 10 geographic populations of $L$. orbonalis and found that all these populations were closely related in their study in Tamil Nadu. Further, our results indicated that there is a stable inherited gene flow among the present population of $L$. orbonalis lessening genetic difference which may be endorsed to passive and active dispersal of the insect besides nonexistence of host-induced disparity among the population. As molecular variability of $L$. orbonalis population is an important consideration for brinjal, constant monitoring is essential to study the possible development of resistance.

\section{Acknowledgements}

The authors wish to thank the authorities of National Bureau of Agricultural Insect Resources (NBAIR), Bengaluru - 560024, Karnataka, India for their facilities to undertake this work. We acknowledge all technical staff who assisted their help in successful completion of work and also farmers who have cooperated for collection of field samples at different places.

\section{References}

Baker, H. G. and Stebbins, G. L. 1965. The genetics of colonizing species, (Academic Press, New York, USA). pp. 588.

Ball, S. L. and Armstrong, K. F. 2006. DNA barcodes for insect pest identification: a test case with tussock moths
(Lepidoptera: Lymantriidae). Canadian J. For. Res., 36 pp. 33.

Barum, L. G, Damiani, C. R., Guglielmino, C., Bandis, A. R., Malacrido and Gasperi, G. 1995. Polymorphism within and between populations of Ceratitis capitala: comparison between RAPD and multilocus enzyme electrophoresis data. Heredity, 74: 425 -437.

Black, W. C., Duteau, N. M., Puterka, G. J., Nechols, J. R. and Pettorini, J. M. 1992. Use of the random amplified polymorphic DNA polymerase chain reaction (RAPD-PCR) to detect DNA polymorphisms in aphids (Homoptera: Aphididae). Bull. Entomol. Res., 87, p. 151.

Boulding, E. G. 1998. Molecular evidence against phylogenetically distinct host races of the pea aphid (Acyrthosiphon pisum).Genome, 42: 769-775.

Chakraborti, S. and Sarkar, P. K. 2011. Management of Leucinodes orbonalis Guenee on eggplants during the rainy season in India. J. Plant Prot. Res., 51(4): $1-7$.

Choudhary, B. 1970. Vegetables. National book trust, New Delhi, pp. 25-50

Dhandapani, N., Shelkar, U. R. and Murugan, M. 2003. Bio-intensive pest management in major vegetable crops: An Indian perspective. J. Food Agric. Environ., 1(2): 330-339.

Eswara Reddy and Srinivasa, S. G. 2004. Management of shoot and fruit borer, Leucinodes orbonalis (Guen.) in brinjal using botanicals/oils. Pestol, 28: 50-52.

Geetha Rajalakshmi, S., Subramanian, S., Shanmugasundaram, P. S. and Mohan Kumar, S. 2006. Molecular analysis of Leucinodes orbonalis guen.populations within Tamil Nadu using lepidopteran specific random primers. Pest Managt. Hort. Ecosy., 12(1): 29-36.

Gissi, C., Iannelli, F. and Pesole, G. 2008. Evolution of the mitochondrial genome 
of metazoa as exemplified by comparison of congeneric species. Heredity, 101: 301-320.

Guirao, P., Beitia, F. and Cenis, J. L. 1997. Biotype determination in Spanish populations of Bemisia tabaci (Hemiptera: Aleyrodidae), Bull. Entomol. Res., 87:587.

Gurubban, G. J. H. 1977. Tropical vegetables and their genetic resources. Internat. Board Pl. Genet. Res., pp. 34-37.

Hartl, D. L. 1980. Principles of population genetics (Sinauer Associates, Sunderland, Massachusetts, USA) pp. 488.

Haymer, D. S. and Mcinnis, D. O. 1994. Resolution of populations of the Mediterranean fruit fly at the DNA level using random primers for the polymerase chain reaction. Genome, 37 , p. 244.

Haymer, D. S., Mei, H. and Mcinnis, D. O. 1997. Genetic. marker analysis of spatial and temporal relationships among existing populations and new infestations of the Mediterranean fruit fly (Ceratitis capitata). Heredity, 79: 302-309.

Hebert, P. D. N., Penton, E. H., Burns, J. M., Janzen, D. H. and Hallwachs, W. 2004. Ten species in one: DNA barcoding reveals cryptic species in the neotropical skipper butterfly, Astraptes fulgerator.Proc. Natl. Acad. Sci., USA, 101 pp. 14812.

Hemi, M. A. 1955. Effect of borer attach on the vitamin ' $\mathrm{C}$ ' content of brinjal. Pakistan J. Health., 4: 223-224.

Infante Malachias, M. E., Yotoko, K. S. and De Azeredoespin, A. M. L. 1999. Random amplified polymorphic DNA of screwworm fly population (Diptera: Calliphoridae) from SouthEastern Brazil and Northern Argentina. Genome, 42: 772-779.

Jagginavar, S. B., Sunitha, N. D., Biradar, A.
P. 2009. Bioefficacy of flubendiamide 480 SC against brinjal fruit and shoot borer, Leucinodes orbonalis Guen. Karnataka J. Agric. Sci., 22(3): 712713.

Jhala, R. C., Patel, M. G., Chanda, A. J. and Patel, Y. C. 2003. Testing IPM strategy for Leucinodes orbonalis in farmer's field. In: Proceedings of the national symposium on frontiers of entomological research (Eds.: B. Subrahmanyam and V.V. Ramamurthy). 5-7 November, New Delhi.p. 256.

John, D. N., Steplien, B. H. and Frederick, R. W. 2002. Evalwiol/, 56: 1475-1488.

Kalloo, G. 1988. Biochemical basis of insect resistance in vegetables.Vegetable Breeding (Vol. II), CRC Press Inc Boca Raton, Florida. pp. 520-570.

Karthikeyan, K. A. M., Vijayakumar, I., Murali, P., Suresh, P. and Janarthanan, S. 2005. Detection of genetic polymorphism in the populations of brinjal shoot and fruit borer, Leucinodes orbonalis (Guenee). Indian J. Exp. Biol., 43: 548-551.

Lal, O. P., Sharma, R. K., Verma, T. S., Bhagchandani, P. M. and Chandra, J. 1976. Resistance in brinjal to shoot and fruit borer, Leucinodes orbonalis Guenee (Pyralidae: Lepidoptera). Veg. Sci., 3: 111-115.

Lynch, M. and Milligan, B. G. 1994. Estimation of relatedness by DNA fingerprinting. Mol. Ecol., 3: 91-99.

Marcon, P. C. R. G., Taylor, D. B., Mason, C. E., Hellmich, R. L. and Siegfried, B. 1999. Genetic similarity among pheromone and voltinism races of Ostrinia nubilalis (Hubner) (Lepidoptera: Crambidae). Insect Mol. Biol., 8 pp. 213.

Marimuthu, M., Perumal, Y., Salim, A. P. and Sharma, G. 2009. Genetic similarity of eggplant shoot and fruit Borer, Leucinodes orbonalis, 
Populations.DNA and Cell Biology, 28(12): $\quad$ 599-603. doi:10.1089/dna.2009.0920.

Mullis, K. B. and Faloona, F. A. 1987. Specific synthesis of DNA in vitro via a polymerase-catalyzed chain reaction. Methods Enzymol, 155, p. 335.

Patil, P. D. 1990. Technique for mass rearing of the brinjal shoot and fruit borer, Leucinodes orbonalis Guen. J. Entomol. Res., 14:164-172.

Perring, T. M. 2001. The Bemisia tabaci species complex. Crop Prot., 20 pp. 725.

Raja, J., Rajendran, B. And Pappiah, C. M. 1999. Management of brinjal shoot and fruit borer (Leucinodes orbonalis Guen.). Veg. Sci., 26: 167-169.

Saiki, R. K., Gelfand, D. H., Stoffel, S., Scharf, S. J., Higuchi, R., Horn, G. T., Mullis, K. B. and Erlich, H. A. 1988. Primer directed enzymatic amplification of DNA with a thermostable DNA polymerase. Sci., 239, p. 487.

Sasikala, Rao, P. A and Krishnayya, P. V. 1999. Comparative efficacy of ecofriendly methods involving egg parasitoid, Trichogramma japonicum, mechanical control and safe chemical against Leucinodes orbonalis Guenee infesting brinjal. J. Entomol. Res., 23: 369-372.

Shashank, P. R., Rakshit Ojha, Venkatesan, T., Jalali, S. K. and Bhanu, K. R. M.
2015. Molecular characterization of brinjal shoot and fruit borer, Leucinodes orbonalis (Guenée) (Lepidoptera: Crambidae) based on mitochondrial marker cytochrome oxidase I and their phylogenetic relationship. Indian $J$. Exp. Biol., 52: 51-55.

Smith, T. B. and Wayne, R. K. 1996. Molecular genetic approaches in conservation, Oxford University Press, Oxford.

Symondson, W. O. C. and Liddell, J. E. 1996. The ecology of agricultural pests: biochemical approaches. Chapman \& Hall, London.

Toda, S. and Murai, T. 2007. Phylogenetic analysis based on mitochondrial COI gene sequences in Thrips tabaci Lindeman (Thysanoptera: Thripidae) in relation to reproductive forms and geographical distribution. Appl. Entomol. Zool., 42 pp. 309.

Williams, C. L., Goldson, S. L., Baird, D. B. and Bullock, D. W. 1994. Geographical origin of an introduced insect pest, Listronotus bonariensis (Kuschel), determined by RAPD analysis. Heredity, 72, p. 412.

Williams, J. G. K., Kubelik, A. R., Livak, K. J., Rafalski, J. A. and Tingey, S. V. 1990. DNA polymorphisms amplified by arbitrary primers are useful as genetic markers. Nucleic Acids Res., 18, p. 6531.

\section{How to cite this article:}

Murali, S., S.K. Jalali, A.N. Shylesha, T.M. Shivalinga Swamy, Reeta Baskar and Prathibha Mruthunjayaswamy. 2017. Molecular Characterization and their Phylogenetic Relationship Based on Mitochondrial Cytochrome Oxidase I of Brinjal Shoot and Fruit Borer, Leucinodes orbonalis (Guenée) (Lepidoptera: Pyralidae). Int.J.Curr.Microbiol.App.Sci. 6(7): 2527-2539. doi: https://doi.org/10.20546/ijcmas.2017.607.298 